\title{
Avaliação de Características de Valor Nutritivo das Gramíneas Forrageiras Marandu, Setária e Tanzânia nas Estações do Ano ${ }^{1}$
}

\author{
Luciana Gerdes², Joaquim Carlos Werner³ ${ }^{3}$ Maria Tereza Colozza4, Rosana Aparecida \\ Possenti ${ }^{4}$, Eliana Aparecida Schammass ${ }^{4}$
}

\begin{abstract}
RESUMO - Foi realizado um experimento de campo, em blocos completos ao acaso, em esquema de parcelas subdivididas, com 12 repetições, com o objetivo de comparar os teores de proteína bruta (PB), fibra em detergente neutro (FDN) e digestibilidade in vitro da matéria seca (DIVMS), da planta inteira e suas frações lâmina e haste do Marandu (Brachiaria brizantha Stapf. cv. Marandu), da setária (Setaria sphacelata [Schum.] Moss var. sericea [Stapf.] cv. Kazungula) e do Tanzânia (Panicum maximum Jacq. cv. Tanzânia-1), em cortes aos 35 dias de crescimento, nas estações de primavera (21/11 a 25/12/97), verão (29/12/97 a 02/02/98), outono (13/04 a 18/05/98) e inverno (28/05/98 a 01/07/98). As parcelas foram representadas pelas gramíneas forrageiras e as subparcelas, pelas estações do ano. Marandu e Tanzânia não diferiram quanto aos teores de PB e DIVMS. A Setária apresentou teores de PB mais elevados que o Marandu, no outono e no inverno, porém menor DIVMS que este, nas quatro estações. Tanzânia e Setária não diferiram quanto aos seus teores de PB e DIVMS, nas quatro estações. Os teores de FDN foram maiores no Tanzânia, mas não diferiram entre Marandu e Setária. O mais alto valor nutritivo, considerando-se maiores teores de proteína e DIVMS e menores teores de FDN, foram observados no outono, independentemente da espécie forrageira.
\end{abstract}

Palavras-chave: digestibilidade in vitro da matéria seca, fibra em detergente neutro, proteína bruta

\section{Evaluation of Nutritive Characteristics of the Grasses Brachiaria brizantha cv. Marandu, Setaria sphacelata cv. Kazungula and Panicum maximum cv. Tanzânia-1 in the Seasons of the Year}

\begin{abstract}
A field plot experiment was conducted, in a split plot design with 12 replications to compare the percentages of crude protein (CP), neutral detergent fibber (NDF) and in vitro dry matter disappearance (IVDMD), of the whole plant and its leaf blades and stems of the grasses Marandu (Brachiaria brizantha Stapf. cv. Marandu), Setaria (Setaria sphacelata cv. Kazungula ) and Tanzania (Panicum maximum Jacq. cv. Tanzania-1) in cuts taken at 35 days of growth in the spring (11/21 to 12/25/97), summer (12/29/97 to 02/02/98), fall (04/13 to 05/18/98) and winter (05/28/98 to 07/01/98). The plots were the grasses and the split-plots were the year seasons. Marandu and Tanzania did not differ for the CP and IVDMD percentages, but Tanzania NDF was higher than the ones of the other two grasses. Setaria showed high levels of CP but the least IVDMD. The best nutritive value, considering higher CP and IVDMD and lower NDF percentages, was observed during the autumn, for the three grasses.
\end{abstract}

Key Words: crude protein, in vitro dry matter disappearance, neutral detergent fibber

\section{Introdução}

Nas décadas de 60 e 70, teve início, no Brasil Central, a utilização da Setaria sphacelata com os cultivares Kazungula, Narok e Nandi, seguidos pela utilização das braquiárias, como a Brachiaria decumbens IPEAN e Basilisk, B. ruziziensis e $B$. Humidicola. Já nas décadas de 80 e 90 passaram a ser utilizadas, respectivamente, duas novas forrageiras, B. brizantha Stapf. cv. Marandu e P. maximum Jacq. cv. Tanzânia-1 (ZIMMER e CORREA, 1993).
O conceito do termo "valor nutritivo" refere-se à composição química da forragem e sua digestibilidade. Já a qualidade de uma planta forrageira é representada pela associação da composição bromatológica, da digestibilidade e do consumo voluntário, entre outros fatores, da forragem em questão (MOTT, 1970). Por isso, é de grande importância o conhecimento dos teores de proteína bruta, fibra bruta e matéria seca, além de outros componentes, e a digestibilidade in vitro da matéria seca, quando se iniciam as avaliações de uma planta promissora (MOTT, 1970; NUNES et al., 1985).

\footnotetext{
1 Parte da Dissertação de Mestrado da primeira autora. Projeto Financiado pelo Tesouro do Estado de São Paulo e FAPESP.

2 Engo-Agroo, MS em Nutrição Animal da FMVZ - USP, campus de Pirassununga e estagiária do Centro de Forragicultura e Pastagens do Instituto de Zootecnia, CP 60, CEP 13460-000, Nova Odessa/SP.

3 Orientador da primeira autora e Pesquisador do Instituto de Zootecnia de Nova Odessa/SP

4 Pesquisador do Instituto de Zootecnia, CP 60, CEP 13460-000, Nova Odessa/SP, email: cfp@izsp.br
} 
Por outro lado, estes constituintes variam em função da idade, da parte da planta, da época do ano e da fertilidade do solo (WERNER, 1993).

O baixo valor nutritivo das forrageiras tropicais é, freqüentemente, mencionado na literatura. Este valor nutritivo está associado ao reduzido teor de proteína bruta e minerais, ao alto conteúdo de fibra e à baixa digestibilidade da matéria seca (EUCLIDES, 1995).

Teores de proteína bruta inferiores a $7 \%$ na matéria seca de algumas gramíneas tropicais promoveram redução na digestão das mesmas, devido a inadequados níveis de nitrogênio para os microorganismos do rúmen (MILFORD e MINSON, 1966).

O teor de proteína bruta, no verão, foi mais elevado no capim-marandu que no setária. Esta situação foi alterada na estação de outono, quando as duas gramíneas não diferiram quanto a seus teores de PB (POSTIGLIONI, 1996).

COSTA (1995) constatou que a melhor idade de corte do cultivar Marandu, visando conciliar produção e teor de proteína, se situa entre 56 e 70 dias.

As forragens tropicais possuem habilidade natural de acumular mais constituintes da parede celular que as espécies de clima temperado (MOORE e MOTT, 1973). Para gramíneas do gênero Panicum, os valores de parede celular inferiores a 55\% são raramente observados, superiores a $65 \%$ são comuns em rebrotas e, em estádios avançados de maturação, situam-se entre 75 e $80 \%$ (EUCLIDES, 1995).

Segundo VAN SOEST (1982), a determinação de fibra bruta, reconhecida na análise bromatológica de Weende, não reflete a qualidade da forragem. Este autor afirma que a técnica de determinação de fibra insolúvel em detergente neutro (FDN) em plantas forrageiras é a melhor estimativa de qualidade. Ainda segundo VAN SOEST (1982), a digestibilidade das gramíneas de clima tropical $\left(\mathrm{C}_{4}\right)$ é menor que a das de clima temperado $\left(\mathrm{C}_{3}\right)$.

A digestibilidade das forrageiras tropicais se situa entre 55 e $60 \%$, podendo diminuir, se a concentração de proteína bruta da forragem for da ordem de 4 a 6\% (MOORE e MOTT, 1973).

O presente trabalho foi conduzido com o objetivo de realizar um estudo comparativo de algumas características de valor nutritivo na planta inteira e nas frações lâminas e hastes do capim-marandu (Brachiaria brizantha Stapf. cv. Marandu), do capim-setária (Setaria sphacelata (Schum.) Moss var. sericea (Stapf.) cv. Kazungula) e do capim-tanzânia (Panicum maximum Jacq. cv.Tanzânia-1) em cortes realizados aos 35 dias de crescimento, nas quatro estações do ano.

\section{Material e Métodos}

O capim-marandu (Brachiaria brizantha Stapf. cv. Marandu), o capim-setária (Setaria sphacelata [Schumach] Moss var. sericea [Stapf.] cv. Kazungula) e o capim-tanzânia (Panicum maximum Jacq. cv. Tanzânia-1) foram plantados em parcelas de $50 \mathrm{~m}^{2}(6,25 \mathrm{~m} \times 8,00 \mathrm{~m})$, dispostas em blocos completos ao acaso, com 12 repetições.

O local do experimento, a correção do solo, a adubação de plantio, a densidade de semeadura e os detalhes do plantio (data de plantio e espaçamento) das três espécies forrageiras em estudo, bem como as condições de precipitação durante a condução do experimento, foram descritos por GERDES et al. (2000).

As características nutricionais foram avaliadas em amostras das forrageiras coletadas após 35 dias de crescimento, nas estações de primavera (21/11 a 25/12/97), verão (29/12/97 a 02/02/98), outono (13/04 a 18/05/98) e inverno (28/05 a 01/07/98). No início do primeiro período de crescimento (21/11/97), as gramíneas foram roçadas a $15 \mathrm{~cm}$ de altura e, após as amostragens de cada estação, foram pastejadas e novamente rebaixadas mecanicamente a $15 \mathrm{~cm}$ de altura para o crescimento do período seguinte. No início do crescimento de outono (13/04/98), logo após o corte de rebaixamento, foram aplicados, em cobertura, $100 \mathrm{~kg} / \mathrm{ha}$ de nitrogênio e $60 \mathrm{~kg} / \mathrm{ha}$ de $\mathrm{K}_{2} 0$.

As amostragens foram feitas em quatro pontos dentro de cada parcela, por meio do lançamento, ao acaso, de um quadrado de $0,5 \times 0,5 \mathrm{~m}\left(0,25 \mathrm{~m}^{2}\right)$. O corte foi feito, à altura de $15 \mathrm{~cm}$ do solo, com tesoura de poda. O material verde colhido nos quatro pontos de cada parcela foi juntado $\left(1 \mathrm{~m}^{2}\right)$ e pesado. Do mesmo, foi retirada amostra para pesagem e secagem em estufa de circulação forçada de ar, regulada a $65^{\circ} \mathrm{C}$. Após secagem, até peso constante, as amostras foram novamente pesadas, para determinação do teor de matéria seca $\left(\% \mathrm{MS} 65^{\circ} \mathrm{C}\right)$ da planta inteira. Também, foram retiradas outras amostras do material verde colhido, para separação de lâminas e hastes de cada perfilho. Estas amostras foram colocadas em estufa para secagem $\left(65^{\circ} \mathrm{C}\right)$, sem, contudo, avaliar o seu peso verde. Devido à pequena quantidade de material vegetal disponível para as análises de proteína bruta $(\mathrm{PB})$, fibra insolúvel em detergente neutro (FDN) e digestibilidade in vitro da matéria seca (DIVMS), foi necessário juntar duas a duas as doze repetições, resultando seis repetições por tratamento. Em seguida, todas as amostras foram moídas, em moinho tipo Willey, com peneira de 40 mesh. 
A proteína bruta foi estimada pela análise do $\mathrm{N}$ total multiplicado pelo fator 6,25 . O N total foi determinado pelo método proposto por SARRUGE e HAAG (1974). As análises de FDN foram realizadas segundo o método de GOERING e VAN SOEST (1970). As determinações de digestibilidade in vitro da matéria seca foram realizadas pelo método proposto por TILLEY e TERRY (1963), modificado por TINIMIT (1974). Todas as determinações foram realizadas na matéria seca a $65^{\circ} \mathrm{C}$ e os resultados, expressos na matéria seca a $105^{\circ} \mathrm{C}$.

O delineamento experimental adotado foi de blocos ao acaso em esquema de parcelas subdivididas para as variáveis em estudo, em que as parcelas eram representadas pelas gramíneas forrageiras e as subparcelas, pelas estações do ano, de acordo com o seguinte modelo estatístico:

$$
\mathrm{Y}_{\mathrm{ijk}}=\mu+\gamma_{\mathrm{i}}+\beta_{\mathrm{j}}+\varepsilon_{\mathrm{ij}}+\pi_{\mathrm{k}}+\gamma \pi_{\mathrm{ik}}+\varepsilon_{\mathrm{ijk}}
$$

em que

$Y_{\mathrm{ijk}}=$ variáveis dependentes: teores de proteína bruta, fibra insolúvel em detergente neutro e digestibilidade in vitro da matéria seca, nos cortes ao $35^{\circ}$ dia de crescimento da gramínea i, no bloco j, na estação $\mathrm{k}$;

$\mu$ = média da população;

$\gamma_{i}=$ efeito da gramínea $i$, em que $\mathrm{i}=1,2,3$;

$\beta_{\mathrm{j}}=$ efeito do bloco $\mathrm{j}$, em que $\mathrm{j}=1,2, \ldots, 6$;

$\varepsilon_{\mathrm{ij}}=$ erro aleatório associado a cada observação ij;

$\pi_{\mathrm{k}}=$ efeito da estação $\mathrm{k}$, em que $\mathrm{k}=1,2, \ldots, 4$;

$\gamma \pi_{\mathrm{ik}}=$ efeito da interação entre gramínea i e estação k; e

$\varepsilon_{i j k}=$ erro aleatório associado a cada observação ijk.

Foram utilizados os procedimentos GLM e ANOVA e as comparações das médias através do teste Tukey a 5\%, do programa estatístico SAS Institute (1989).

\section{Resultados e Discussão}

\section{Proteína bruta}

Houve interação $(\mathrm{P}<0,05)$ gramínea $\mathrm{x}$ estações do ano para a porcentagem de proteína bruta na planta inteira. Não se observou diferença $(\mathrm{P}>0,05) \mathrm{de}$ teores de proteína bruta entre as gramíneas nas estações de primavera e verão (Tabela 1). Já no outono e no inverno, o capim-setária apresentou teor mais elevado $(\mathrm{P}<0,05)$ que o capim-marandu, mas semelhantes $(\mathrm{P}>0,05)$ ao do Tanzânia. Este último, por sua vez, mostrou teores de proteína não diferentes $(\mathrm{P}>0,05)$ aos do Marandu.

MACEDO et al. (1993), comparando o teor de proteína bruta de três cultivares de $P$. maximum, entre eles o capim-tanzânia, com duas espécies do gênero Brachiaria (B. brizantha e B. decumbens), nos períodos das águas e da seca, verificaram que os teores de proteína sempre foram maiores nos Panicuns que nas Brachiarias, independentemente dos períodos, embora esta diferença tenha sido de pequena magnitude.

EUCLIDES et al. (1993) encontraram para o capim-colonião, capim-tobiatã e capim-tanzânia teores de proteína bruta de 9,$5 ; 9,1$; e 7,4\%, respectivamente. Nota-se, assim, certa semelhança entre as gramíneas. Segundo EUCLIDES (1995), os cultivares de $P$. maximum, comparados sob as mesmas condições experimentais, apresentam pequena variação de valor nutritivo.

POSTIGLIONI (1996) analisou amostras de capim-marandu e capim-setária, colhidas mensalmente para comparar os teores de proteína bruta ao longo das estações do ano. Não foram constatadas diferenças nos teores de PB nas duas gramíneas, nas estações de primavera e outono, sendo que, no verão, o Marandu foi superior à Setária.

Analisando o comportamento das gramíneas nas quatro estações (Tabela 1), verifica-se que o capimmarandu e o capim-tanzânia mostraram a mesma tendência ao longo das estações. Ambos apresentaram teores mais elevados $(\mathrm{P}<0,05)$ no outono, intermediários no inverno e na primavera e menores $(\mathrm{P}<0,05)$ no

Tabela 1 - Teores de proteína bruta (PB) da planta inteira das gramíneas Marandu, Setária e Tanzânia amostradas aos 35 dias nas estações de primavera, verão, outono e inverno. Médias de seis repetições

Table 1 - Crude protein (CP) percentage in the tops of Marandu, Setaria and Tanzania grasses at 35 days of growth during spring, summer, fall and winter. Means of six replications

\begin{tabular}{lcccc}
\hline & \multicolumn{4}{c}{$\mathrm{PB}(\%)$} \\
Capim & \multicolumn{4}{c}{$C P$} \\
nrass & $\begin{array}{c}\text { Primavera } \\
\text { Spring }\end{array}$ & $\begin{array}{c}\text { Verão } \\
\text { Summer }\end{array}$ & $\begin{array}{c}\text { Outono } \\
\text { Fall }\end{array}$ & $\begin{array}{c}\text { Inverno } \\
\text { Winter }\end{array}$ \\
\hline Marandu & $12,83^{\mathrm{Ba}}$ & $11,40^{\mathrm{Ca}}$ & $18,58^{\mathrm{Ab}}$ & $13,71^{\mathrm{Bb}}$ \\
Setária & $12,66^{\mathrm{Ca}}$ & $10,59^{\mathrm{Da}}$ & $21,00^{\mathrm{Aa}}$ & $16,30^{\mathrm{Ba}}$ \\
Tanzânia & $13,69^{\mathrm{Ba}}$ & $10,84^{\mathrm{Ca}}$ & $19,76^{\mathrm{Aab}}$ & $15,27^{\mathrm{Bab}}$ \\
CV\% (capins) & & 7,28 & & \\
CV\% (grasses) & & & \\
CV\% (estações) & 7,23 & & \\
CV\% (seasons) & & & \\
\hline
\end{tabular}

Médias seguidas de mesma letra, minúscula nas colunas e maiúscula nas linhas, não diferem $(P>0,05)$ pelo teste Tukey.

Means followed by the same letter, small in the same column and capital in the same row, do not differ $(P>.05)$ by Tukey test. 
verão. Já a Setária apresentou teores de PB diferentes $(\mathrm{P}<0,05)$ para cada estação, na seguinte ordem decrescente: outono, inverno, primavera e verão.

Os teores mais elevados de proteína bruta no outono podem ser explicados por se ter efetuado adubação nitrogenada no início do período de crescimento de outono e terem sido realizados cortes sempre em um período de crescimento de 35 dias (menor velocidade de crescimento nesta época do ano, em relação à de primavera e verão e, conseqüentemente, maior proporção de lâminas foliares em relação às duas estações anteriores, como discutidos em GERDES et al. [2000]).

Nas quatro estações, avaliaram-se os teores protéicos nas frações lâminas e hastes das plantas das três espécies (Tabela 2).

Comparando-se as três espécies quanto às concentrações de PB nas lâminas e nas hastes, na média das quatro estações, verifica-se que o capimsetária se destacou, apresentando os teores mais elevados $(\mathrm{P}<0,05)$, tanto nas lâminas quanto nas hastes. As lâminas do Marandu e Tanzânia não diferiram entre si $(\mathrm{P}>0,05)$, enquanto nas hastes os teores foram mais elevados $(\mathrm{P}<0,05)$ para o Marandu, quando comparado com o Tanzânia.

Estes resultados de teores de PB das lâminas do Marandu e do Tanzânia coincidem com os resultados encontrados por EUCLIDES (1995), quando compararam estas duas espécies nos períodos das águas e seca. Já nas hastes das mesmas espécies, essa autora encontrou os maiores teores no Tanzânia.

Comparando-se os teores de proteína bruta nas lâminas e nas hastes, para as médias dos três capins em cada estação do ano (Tabela 2), verifica-se que, para as lâminas, os maiores $(\mathrm{P}<0,05)$ teores foram encontrados no outono; os intermediários, na primavera e no inverno; e os menores $(\mathrm{P}<0,05)$, no verão. Já para as hastes, os maiores $(\mathrm{P}<0,05)$ teores também foram encontrados no outono e os menores $(\mathrm{P}<0,05)$, também no verão. Entretanto, na

Tabela 2 - Teores de proteína bruta (PB) das lâminas e das hastes das gramíneas Marandu, Setária e Tanzânia amostradas aos 35 dias nas estações de primavera, verão, outono e inverno. Médias de seis repetições

Table 2 - Crude protein (CP) percentage in the leaf blade and in the stem of Marandu, Setaria and Tanzania at 35 days of growth during spring, summer, fall and winter. Means of six replications

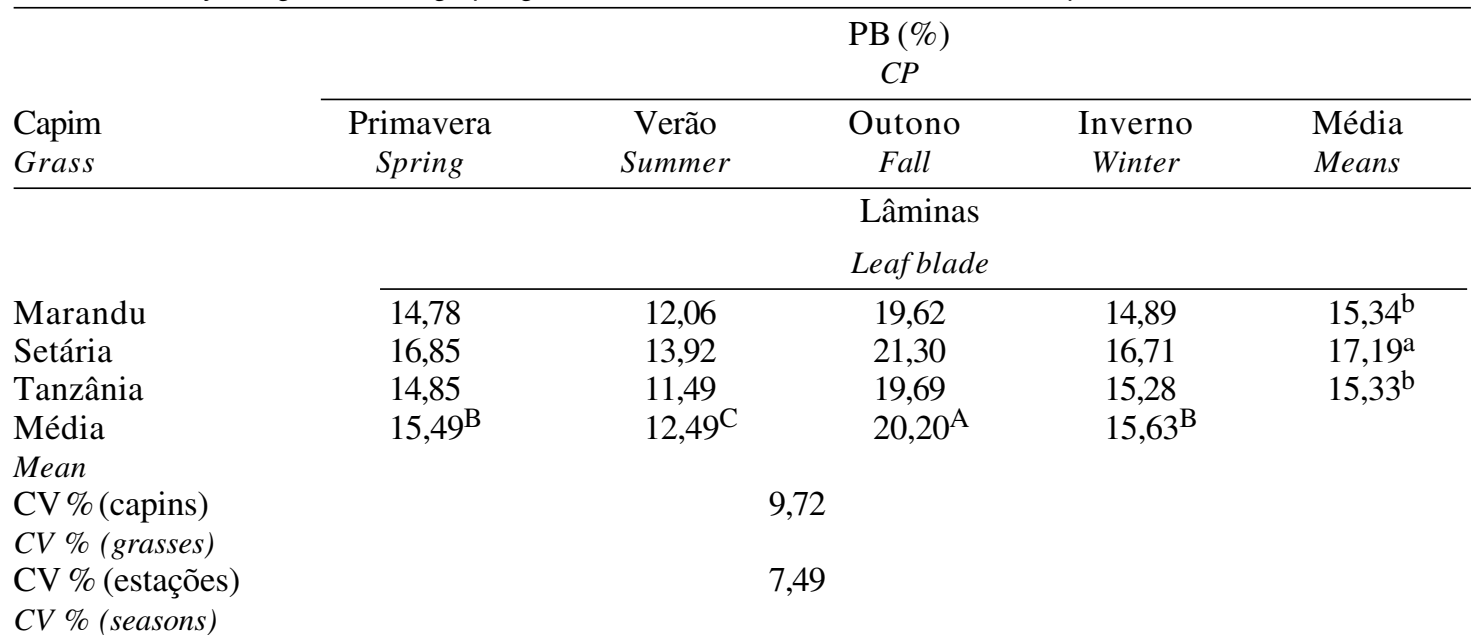

\begin{tabular}{|c|c|c|c|c|c|}
\hline \multirow[b]{3}{*}{ Marandu } & \multicolumn{5}{|c|}{ Hastes } \\
\hline & \multicolumn{5}{|c|}{ Stem } \\
\hline & 9,19 & 7,64 & 11,50 & 7,87 & $9,05^{\mathrm{b}}$ \\
\hline Setária & 9,85 & 7,62 & 12,94 & 9,22 & $9,91^{\mathrm{a}}$ \\
\hline Tanzânia & 8,01 & 5,73 & 9,80 & 6,77 & $7,58^{\mathrm{c}}$ \\
\hline Média & $9,02^{\mathrm{B}}$ & $7,00^{\mathrm{D}}$ & $11,41^{\mathrm{A}}$ & $7,95^{\mathrm{C}}$ & \\
\hline \multicolumn{6}{|l|}{ Mean } \\
\hline CV \% (capins) & & & & & \\
\hline \multicolumn{6}{|l|}{$C V \%$ (grasses) } \\
\hline \multicolumn{6}{|l|}{ CV \% (estações) } \\
\hline$C V \%$ (seasons) & & & & & \\
\hline
\end{tabular}

Médias seguidas de mesma letra, para a mesma parte, minúscula nas colunas e maiúscula nas linhas, não diferem $(\mathrm{P}>0,05)$ pelo teste Tukey.

Means followed by the same letter, for the same part, small in the same column and capital in the same row, do not differ ( $P>.05)$ by Tukey test. 
primavera, os teores de PB nas hastes foram maiores $(\mathrm{P}<0,05)$ que aqueles no inverno.

EUCLIDES (1995) encontrou as maiores porcentagens de PB, tanto nas folhas, quanto nas hastes, de capim-marandu e capim-tanzânia, nas águas.

As razões de os maiores teores de proteína bruta, tanto nas lâminas quanto nas hastes, terem ocorrido no outono, no presente trabalho, podem ter a mesma explicação já descrita quando da discussão de proteína bruta na planta inteira.

Fibra insolúvel em detergente neutro

Houve interação $(\mathrm{P}<0,05)$ entre gramíneas $\mathrm{x}$ estações para os teores de fibra insolúvel em detergente neutro (FDN) na planta inteira (Tabela 3). No seu desdobramento, quando se compararam gramíneas conforme a estação, verificou-se que, nas quatro estações avaliadas, o Tanzânia apresentou teores de FDN mais elevados $(\mathrm{P}<0,05)$ que os das outras duas, que não diferiram $(\mathrm{P}>0,05)$. Já no estudo de estações para cada gramínea, o FDN do Marandu decresceu $(\mathrm{P}<0,05)$ na seguinte seqüência: verão, primavera, inverno e outono. Para a Setária, os maiores $(\mathrm{P}<0,05)$ teores de FDN foram encontrados na primavera e verão; teor intermediário no inverno; e menor no outono $(\mathrm{P}<0,05)$. $\mathrm{O}$ teor de FDN para o capim-tanzânia foi mais elevado $(\mathrm{P}<0,05)$ no verão, que diferiu $(\mathrm{P}<0,05)$ daquele da primavera, que, por sua vez, foram mais elevados $(\mathrm{P}<0,05)$ que os do outono e inverno. Com a rápida elongação da haste das gramíneas no verão, especialmente na Setária, a participação do constituinte parede celular é maior e, conseqüentemente, a concentração de proteína bruta é mais baixa, como se pode ver na Tabela 1 .

Tanto nas frações lâminas como nas de hastes, os teores de FDN (Tabela 4) sofreram interação $(\mathrm{P}<0,05)$ gramíneas x estações, no estudo da análise de variância dos dados obtidos.

Apesar de o delineamento experimental adotado não ter permitido a comparação das partes (lâminas e hastes), vale a pena chamar a atenção para o fato de, nas três gramíneas e nas quatro estações do ano, os teores de FDN das hastes terem sido sempre superiores aos das lâminas. É interessante observar, também, que os teores maiores de proteína bruta (Tabela 2) ocorreram nas lâminas foliares.

Analisando os teores de FDN nas lâminas (Tabela 4) das gramíneas, comparando-as em cada estação, pode-se observar que este constituinte no tanzânia, nas quatro estações, foi maior $(\mathrm{P}<0,05)$ que no Marandu e na Setária. Estas duas últimas, entretanto, não diferiram $(\mathrm{P}>0,05)$ nos seus teores de FDN, como aconteceu na planta inteira (Tabela 3).

Os teores de FDN nas hastes (Tabela 4) das três gramíneas, no inverno, não foram analisados, em razão da limitação da quantidade de material das amostras para esta determinação, ocorrendo o mesmo, no outono, para o capim-marandu. Na primavera, o teor mais elevado $(\mathrm{P}<0,05)$ de FDN se encontra nas hastes do Tanzânia, em seguida nas do Marandu $(\mathrm{P}<0,05)$ e o menor $(\mathrm{P}<0,05)$ nas da Setária. No verão, os teores de FDN não diferiram $(\mathrm{P}>0,05)$

Tabela 3 - Teores de fibra em detergente neutro (FDN) da planta inteira das gramíneas Marandu, Setária e Tanzânia amostradas aos 35 dias nas estações de primavera, verão, outono e inverno. Médias de seis repetições

Table 3 - Neutral detergent fiber (NDF) percentage in the tops of Marandu, Setaria and Tanzania grasses at 35 days of growth, during spring, summer, fall and winter. Means of six replications

\begin{tabular}{lcccc}
\hline & \multicolumn{4}{c}{ FDN $(\%)$} \\
Capim & \multicolumn{5}{c}{ NDF } \\
\cline { 2 - 5 } Grass & $\begin{array}{c}\text { Primavera } \\
\text { Spring }\end{array}$ & $\begin{array}{c}\text { Verão } \\
\text { Summer }\end{array}$ & $\begin{array}{c}\text { Outono } \\
\text { Fall }\end{array}$ & $\begin{array}{c}\text { Inverno } \\
\text { Winter }\end{array}$ \\
\hline Marandu & $68,81^{\mathrm{Bb}}$ & $72,70^{\mathrm{Ab}}$ & $57,92^{\mathrm{Db}}$ & $62,30^{\mathrm{Cb}}$ \\
Setária & $70,74^{\mathrm{Ab}}$ & $71,56^{\mathrm{Ab}}$ & $58,76^{\mathrm{Cb}}$ & $62,99^{\mathrm{Bb}}$ \\
Tanzânia & $74,75^{\mathrm{Ba}}$ & $78,14^{\mathrm{Aa}}$ & $65,64^{\mathrm{Ca}}$ & $66,32^{\mathrm{Ca}}$ \\
\hline CV \% (capins) & & & & \\
CV \% (grasses) & & & 2,23 & \\
CV \% (estações) & & 2,00 & \\
CV \% (seasons) & & & & \\
\hline
\end{tabular}

Médias seguidas de mesma letra, minúscula nas colunas e maiúscula nas linhas, não diferem $(\mathrm{P}>0,05)$ pelo teste Tukey.

Means followed by the same letter, small in the same column and capital in the same row, do not differ ( $P>.05)$ by Tukey test. 
Tabela 4 - Teores de fibra em detergente neutro (FDN) das lâminas e das hastes das gramíneas Marandu, Setária e Tanzânia amostradas aos 35 dias nas estações de primavera, verão, outono e inverno. Médias de seis repetições

Table 4 - Neutral detergent fiber (NDF) percentage in the leaf blade and in the stem of Marandu, Setaria and Tanzania grasses at 35 days of growth, during spring, summer, fall and winter. Means of six replications

\begin{tabular}{|c|c|c|c|c|}
\hline \multirow{3}{*}{$\begin{array}{l}\text { Capim } \\
\text { Grass }\end{array}$} & \multicolumn{4}{|c|}{$\begin{array}{c}\mathrm{FDN}(\%) \\
N D F\end{array}$} \\
\hline & Primavera & Verão & Outono & Inverno \\
\hline & Spring & Summer & Fall & Winter \\
\hline & \multicolumn{4}{|c|}{ Lâminas } \\
\hline Marandu & $67,01^{\mathrm{Bb}}$ & $73,95^{\mathrm{Ab}}$ & $59,74^{\mathrm{Cb}}$ & $64,80^{\mathrm{BCb}}$ \\
\hline Setária & $66,47^{\mathrm{Bb}}$ & $72,41^{\mathrm{Ab}}$ & $61,55^{\mathrm{Cb}}$ & $63,72^{\mathrm{BCb}}$ \\
\hline Tanzânia & $74,78^{\mathrm{Ba}}$ & $78,87^{\mathrm{Aa}}$ & $70,69^{\mathrm{Ca}}$ & $67,70^{\mathrm{Da}}$ \\
\hline CV\% (capins) & & & & \\
\hline$C V \%$ grasses & \multirow{2}{*}{\multicolumn{4}{|c|}{2,24}} \\
\hline CV \% (estações) & & & & \\
\hline CV \% seasons & \multicolumn{4}{|c|}{2,61} \\
\hline & \multicolumn{4}{|c|}{ Hastes } \\
\hline Marandu & $76,59^{\mathrm{Ab}}$ & $77,15^{\mathrm{Aa}}$ & - & - \\
\hline Setária & $73,30^{\mathrm{Bc}}$ & $76,45^{\mathrm{Aa}}$ & $63,66^{\mathrm{Cb}}$ & - \\
\hline Tanzânia & $79,83^{\mathrm{Aa}}$ & $79,31^{\mathrm{Aa}}$ & $72,98^{\mathrm{Ba}}$ & - \\
\hline CV \% (capins) & & & & \\
\hline CV \% (grasses) & \multirow{2}{*}{\multicolumn{4}{|c|}{1,66}} \\
\hline CV \% (estações) & & & & \\
\hline$C V \%$ (seasons) & \multicolumn{4}{|c|}{2,36} \\
\hline
\end{tabular}

Médias seguidas de mesma letra, para a mesma parte, minúscula nas colunas e maiúscula nas linhas, não diferem $(P>0,05)$ pelo teste Tukey.

Means followed by the same letter, for the same part, small in the same column and capital in the same row, do not differ $(P>$.05) by Tukey test.

para as hastes das três gramíneas e, no outono, novamente o Tanzânia apresentou teor mais elevado $(\mathrm{P}<0,05)$, comparado com a Setária.

No estudo dos teores de FDN das lâminas de cada gramínea, em função das estações (Tabela 4), o capim-marandu e o capim-setária apresentaram teores de FDN em maiores $(\mathrm{P}<0,05)$ concentrações no verão, concentrações intermediárias na primavera e menores $(\mathrm{P}<0,05)$ no outono. Os teores, no inverno, não diferiram $(\mathrm{P}>0,05)$ dos da primavera e do outono. Para o Tanzânia, a seqüência das concentrações nas estações foi a seguinte: verão, primavera, outono e inverno, diferindo, estatisticamente $(\mathrm{P}<0,05)$ entre cada estação. Nas hastes, o capim-marandu e o capimtanzânia não diferiram em seus teores de FDN $(\mathrm{P}>0,05)$, comparando-se primavera com verão. Os teores do Tanzânia, no outono, foram menores $(\mathrm{P}<0,05)$ que os da primavera e do verão. Já a Setária mostrou maior $(\mathrm{P}<0,05)$ teor de FDN no verão, teor intermediário na primavera e teor menor $(\mathrm{P}<0,05)$ no outono.
Digestibilidade in vitro da matéria seca

A análise de variância demonstrou que foi significativa $(\mathrm{P}<0,05)$ a interação gramíneas $\mathrm{x}$ estações nas determinações da digestibilidade in vitro da matéria seca (DIVMS) da planta inteira. Na comparação das gramíneas em cada estação (Tabela 5), o Marandu foi sempre mais digestível $(\mathrm{P}<0,05)$ que a Setária, porém não diferiu $(\mathrm{P}>0,05)$ do Tanzânia, que, por sua vez, não diferiu $(\mathrm{P}>0,05)$ da Setária.

Resultados semelhantes para Marandu e Setária foram encontrados em trabalho de POSTIGLIONI (1996), comparando a DIVMS destas duas gramíneas nas estações de primavera, verão e outono.

Apesar de os teores de FDN (Tabela 3) do Marandu e da Setária não terem sido diferentes nas quatro estações e os teores de proteína bruta (Tabela 1) também não diferirem na primavera e verão, mas serem mais elevados na Setária que no Marandu, no outono e inverno, o capim-setária apresentou sempre menor DIVMS que o Marandu, quando se considera 
Tabela 5 - Teores de digestibilidade in vitro da matéria seca (DIVMS) da planta inteira das gramíneas Marandu, Setária e Tanzânia amostradas aos 35 dias nas estações de primavera, verão, outono e inverno. Médias de seis repetições

Table 5 - In vitro dry matter digestibility (IVDMD) percentage in the tops of the grasses Marandu, Setaria and Tanzania grasses at 35 days of growth during spring, summer, fall and winter. Means of six replications

\begin{tabular}{lcccc}
\hline & \multicolumn{5}{c}{$\begin{array}{c}\text { DIVMS }(\%) \\
\text { IVDMD }\end{array}$} \\
\cline { 2 - 5 } Capim & $\begin{array}{c}\text { Primavera } \\
\text { Sprass }\end{array}$ & $\begin{array}{c}\text { Verão } \\
\text { Summer }\end{array}$ & $\begin{array}{c}\text { Outono } \\
\text { Fall }\end{array}$ & $\begin{array}{c}\text { Inverno } \\
\text { Winter }\end{array}$ \\
\hline Marandu & $59,40^{\mathrm{Ba}}$ & $65,68^{\mathrm{ABa}}$ & $71,62^{\mathrm{Aa}}$ & $62,10^{\mathrm{Ba}}$ \\
Setária & $53,27^{\mathrm{Bb}}$ & $59,49^{\mathrm{ABb}}$ & $65,71^{\mathrm{Ab}}$ & $56,39^{\mathrm{Bb}}$ \\
Tanzânia & $56,78^{\mathrm{Bab}}$ & $60,99^{\mathrm{Bab}}$ & $69,96^{\mathrm{Aab}}$ & $61,06^{\mathrm{Bab}}$ \\
\hline CV\% (capins) & \multicolumn{4}{c}{5,71} \\
CV \% (grasses) & \multicolumn{3}{c}{} \\
CV \% (estações) & \multicolumn{3}{c}{6,78} \\
CV \% (seasons) & & & \\
\hline
\end{tabular}

Médias seguidas de mesma letra, minúscula nas colunas e maiúscula nas linhas, não diferem $(P>0,05)$ pelo teste Tukey.

Means followed by the same letter, small in the same column and capital in the same row, do not differ $(P>.05)$ by Tukey test.

a planta inteira. No Tanzânia, apesar de ter sido sempre observada a mais alta concentração de FDN (Tabela 3), não foi detectada diferença de DIVMS entre ele e as outras duas gramíneas.

Segundo NUSSIO et al. (1998), o potencial de digestão da parede celular em plantas do gênero Cynodon parece não ser limitado exclusivamente pela composição química, mas pela participação percentual de determinados tecidos na haste da planta, além da arquitetura da célula. Com isto, as análises de constituintes da parede celular (PC) sofreram grandes progressos com sofisticados recursos de determinação da composição químico-estrutural de plantas forrageiras, revelando a estrutura tridimensional dos constituintes da parede celular, os tipos das ligações éster e éter na associação de ácido ferúlico e p-coumárico, entre outros recursos. JUNG e ALLEN (1995) relataram com detalhes as limitações impostas à digestão da parede celular de gramíneas tropicais. Estudos mais detalhados da parede celular das três gramíneas ora focalizada, usando tais recursos, poderão esclarecer o porquê de o Tanzânia apresentar os mais altos valores de FDN, mas DIVMS semelhante à das outras duas gramíneas.

Quando se estudou o efeito das estações em cada gramínea (Tabela 5), Marandu e Setária apresentaram maior DIVMS $(\mathrm{P}<0,05)$ no outono em relação à primavera e inverno, mas valores não diferentes $(\mathrm{P}>0,05)$ no outono e verão. O Tanzânia, por outro lado, apresentou maior DIVMS $(\mathrm{P}<0,05)$ no outono, comparado com as outras três estações.

Para as frações lâminas foliares (Tabela 6), nas médias das quatro estações do ano, o Marandu foi mais digestível $(\mathrm{P}<0,05)$ que a Setária e não diferiu ( $\mathrm{P}>0,05)$ do Tanzânia, que, por sua vez, também não diferiu $(\mathrm{P}>0,05)$ da Setária. Os resultados de DIVMS das hastes (Tabela 6), considerando-se a média das quatro estações, não diferiram $(\mathrm{P}>0,05)$ entre as três gramíneas.

Valores semelhantes de digestibilidade in vitro da matéria orgânica nas folhas do capim-marandu e do capim-tanzânia foram observados por EUCLIDES (1995). Entretanto, nos caules, os valores no capimmarandu foram menores que nos do Tanzânia.

Comparando-se a média das três gramíneas, nas quatro estações, para as frações lâminas e hastes, a DIVMS das lâminas (Tabela 6) foi maior $(\mathrm{P}<0,05)$ no outono que nas outras três estações; no verão e no inverno, não diferiram $(\mathrm{P}>0,05)$, porém foram maiores $(\mathrm{P}<0,05)$ que na primavera. Para as hastes, as digestibilidades no verão e no outono foram maiores $(\mathrm{P}<0,05)$ que aquelas encontradas na primavera e no inverno.

FISHER et al. (1991) observaram pequena diferença entre a digestibilidade das folhas e caules e acentuada superioridade da digestibilidade do tecido vivo em relação ao material senescente em Cynodon. No presente estudo (Tabela 6), observa-se pequena variabilidade dos valores de digestibilidade entre as frações lâminas e hastes, apesar de não se terem comparado estatisticamente estes valores.

De modo geral, os cultivares de $P$. maximum apresentam valor nutritivo superior aos das gramíneas do gênero Brachiaria, o que é condizente com os maiores conteúdos de PB, P, S e DIVMS, para o gênero Panicum (EUCLIDES, 1995). Entretanto, no presente estudo, Marandu e Tanzânia não diferiram, em todas as estações dos ano, quanto aos seus valores nutritivos (teores de proteína bruta e DIVMS), com exceção do FDN, que foi maior no Tanzânia, sem, contudo, refletir em sua digestibilidade. 
Tabela 6 - Teores de digestibilidade in vitro da matéria seca (DIVMS) das lâminas e das hastes das gramíneas Marandu, Setária e Tanzânia amostradas aos 35 dias nas estações de primavera, verão, outono e inverno. Médias de seis repetições

Table 6 - In vitro dry matter disappearance (IVDMD) percentage in the leaf blade and in the stem of Marandu, Setaria and Tanzania grasses at 35 days of growth during spring, summer, fall and winter. Means of six replications

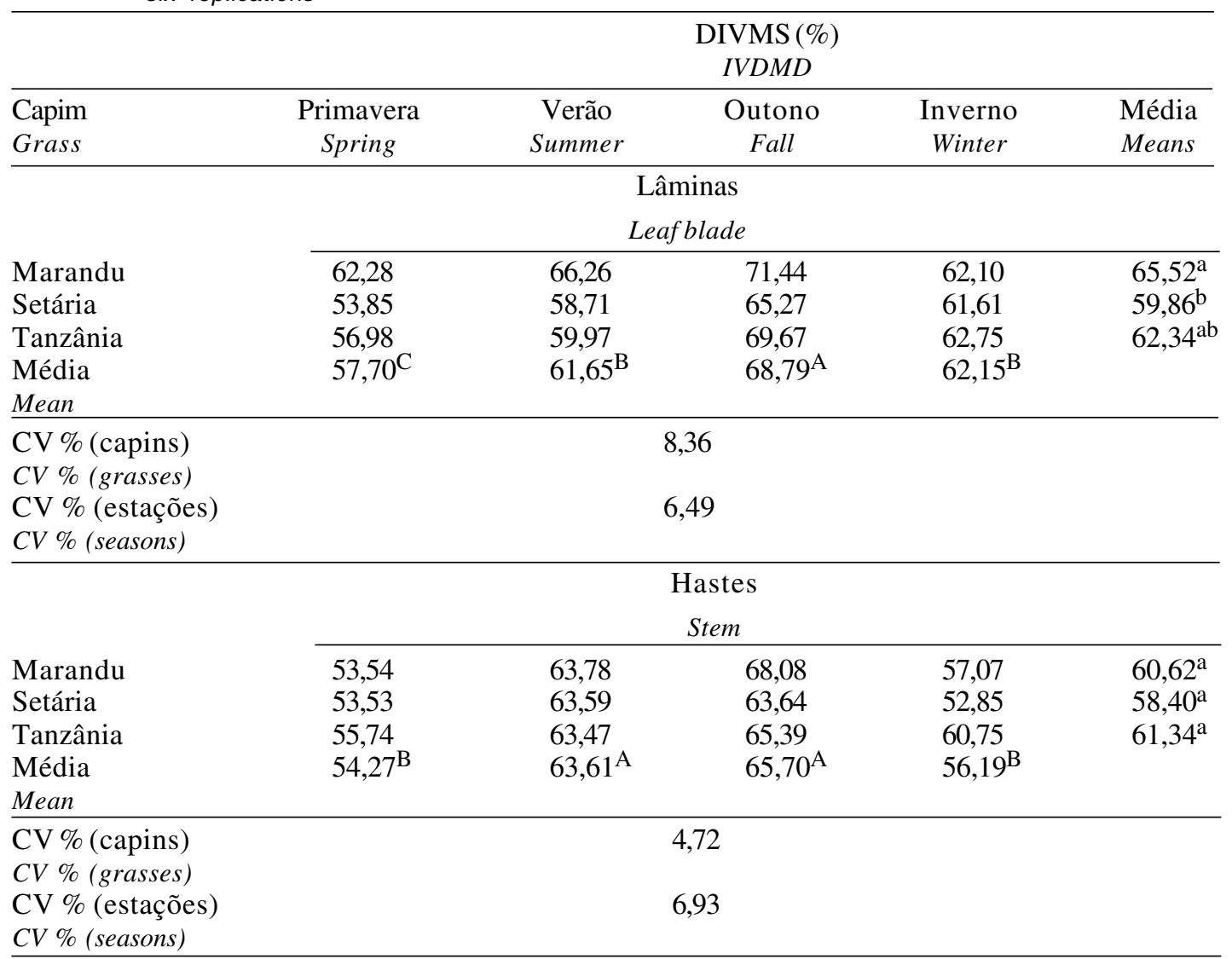

Médias seguidas de mesma letra, para a mesma parte, minúscula nas colunas e maiúscula nas linhas, não diferem $(P>0,05)$ pelo teste Tukey.

Means followed by the same letter, in the same part, small in the same column and capital in the same row, do not differ $(P>.05)$ by Tukey test.

\section{Conclusões}

Marandu e Tanzânia não diferiram quanto ao valor nutritivo (teores de PB e DIVMS), com exceção do teor de FDN, que foi mais elevado no Tanzânia, sem, contudo, reduzir sua digestibilidade.

A Setária apresentou teores de PB mais elevados e DIVMS inferior à do Marandu. Já os teores de FDN destas duas gramíneas não diferiram.

Mais alto valor nutritivo, considerando-se maiores teores de proteína e DIVMS e menores teores de FDN, foi observado no outono, independentemente da espécie forrageira.

\section{Agradecimento}

À Fundação de Amparo à Pesquisa do Estado de São Paulo (FAPESP), pela bolsa de mestrado conce- dida à autora principal, para execução do projeto e ao Instituto de Zootecnia em Nova Odessa, São Paulo, pelo uso da infra-estrutura e pela oportunidade concedida para a realização deste trabalho.

\section{Referências Bibliográficas}

COSTA, N. de L. Curva de crescimento e composição química de Brachiaria brizantha cv. Marandu em Rondônia. In: REUNIÃO ANUAL DA SOCIEDADE BRASILEIRA DE ZOOTECNIA, 32, Brasília, 1995. Anais... Brasília: SBZ, 1995. v.2, p.38-40.

EUCLIDES, V.P.B. Valor alimentício de espécies forrageiras do gênero Panicum. In: SIMPÓSIO SOBRE MANEJO DA PASTAGEM, 12, Piracicaba, 1995. Anais... Piracicaba: FEALQ, 1995. p.245-73.

EUCLIDES, V.P.B., MACEDO, M.C.M., VIEIRA, A. et al. Evaluation of Panicum maximum cultivars under grazing. In: INTERNATIONAL GRASSLAND CONGRESS, 17, Palmerston North, 1993. Proceedings... Palmerston North: New Zealand Grassland Association, 1993. p.1999-2000. 
Rev. bras. zootec.

FISHER, D.S., BURNS, J.C., POND, R.D. et al. 1991. Effects of grass species on grazing steers: I. Diet composition and ingestive mastication. J. Anim. Sci., 69:1188-98.

GERDES, L., WERNER, J.C., COLOZZA, M.T. et al. 2000. Algumas características agronômicas e morfológicas dos capins marandu, setária e tanzânia aos 35 dias de crescimento nas estações do ano. Rev. bras. zootec., 29(4):947-954.

GOERING, N.K., VAN SOEST, P.J. 1970. Forage fiber analysis: apparatus, reagents, procedures and some application. Washinghton. 20p. (USDA.Agriculture Handbook).

JUNG, H.G., ALLEN, M.S. 1995. Characteristics of plant cell walls affecting intake and digestibility of forages by rumunants. J. Anim. Sci., 73:2774-2790.

MACEDO, M.C.M., EUCLIDES, V.P.B., OLIVEIRA, M.P. Seasonal changes in chemical composition of cultivated tropical grasses in the savannas of Brasil. In: INTERNATIONAL GRASSLAND CONGRESS, 17, Palmerston North, 1993. Proceedings... Palmerston North: New Zealand Grassland Association, 1993. p.2000-2002.

MILFORD, R., MINSON, D.J. Intake of tropical pasture species. In: CONGRESSO INTERNACIONAL DE PASTAGEM, 9, 1965, São Paulo. Anais... São Paulo: Secretaria de Agricultura, 1966. p.814-22.

MOORE, J.E., MOTT, G.O. 1973. Structural inhibitors of quality in tropical grasses. In: MATCHES, A.G. Anti quality components offorages. Madison: CSSA, Special publication, n.4, p.53-98.

MOTT, G.O. 1970. Evaluacion de la produccion de forrajes In: HUGHES, H.D., HEATH, M.E., METCALFE, D.S. (Eds.) Forrajes - la ciencia de la agricultura basada en la producción de pastos. México. p.131-141.

NUNES, S.G., BOOCK, A., PENTEADO, M.I. de O. et al. 1985. Comissão da cultivar Marandu. Campo Grande, CNPGC. 31p. (Documentos, 21).

NUSSIO, L.G., MANZANO, R.P., PEDREIRA, C.G.S. Valor alimentício em plantas do gênero Cynodon. In: SIMPÓSIO SOBRE MANEJO DA PASTAGEM, 15, Piracicaba, 1998. Anais... Piracicaba: FEALQ, 1998. p.203-42.
POSTIGLIONI, S.R. Avaliação sob pastejo da Brachiaria brizantha cv. Marandu, Setaria anceps cv. Kazungula e Cynodon dactylon cv. Coastcross-1 na região dos Campos Gerais do Paraná. In: REUNIÃO ANUAL DA SOCIEDADE BRASILEIRA DEZOOTECNIA, 33, Fortaleza, 1996. Anais... Fortaleza: SBZ, 1996, v.2, p.41-43.

SARRUGE, J.R., HAAG, H.P. 1974. Análises químicas em plantas. Piracicaba: ESALQ. 56p.

SAS. Language guide, version 6.03, Ed. Cary: SAS Institute Inc., 1989. 530p.

TILLEY, J.M.A., TERRY, R.A. 1963. A two-stage technique for the in vitro digestion of forage crops. J. Brit. Grassl., 18:104-11.

TINIMIT, P. 1974. Forage evaluation using various laboratory techniques. East Lansing. 135p. (Ph.D. - Michigan State, University).

VAN SOEST, P.J. 1982. Nutritional ecology of the ruminants. New York: Cornell University Press. 373p.

WERNER, J.C. Importância da interação solo-planta-animal na nutrição de ruminantes. In: CURSO DE ATUALIZAÇÃO EM NUTRIÇÃO ANIMAL, v.1, 1993. Brasília: MAARA/ SDR/SENA. Anais.... Brasília, 1993. p.11-20.

ZIMMER, A.H., CORREA, E.S. A pecuária nacional, uma pecuária de pasto? In: ENCONTRO SOBRE RECUPERAÇÃO DE PASTAGENS, Nova Odessa, 1993. Anais... Nova Odessa: Instituto de Zootecnia, 1993. p.1-25.

Recebido em: 28/09/1999

Aceito em: 04/02/2000 